\title{
JAK KUPIEC SYMONOWICZ TRAFIŁ DO POLSKIEJ KOMEDII
}

Premiera Matżeństwa z kalendarza w wykonaniu aktorów narodowych 4 marca 1766 roku zapisała się w historii z kilku powodów. Po spektaklu doszło do konfliktu, a następnie pojedynku między Ksawerym Branickim i Giacomem Casanovą. Dwaj spektatorzy poróżnili się wprawdzie o sprawy baletu (i zwalczających się primabalerin), niemniej stało się to w loży podczas polskiej komedii ${ }^{1}$. Dla dziejów rodzimej sceny ważniejszy jest jednak debiut autorski księdza Franciszka Bohomolca „na theatrum”. Małżeństwo z kalendarza było pierwszą z jedenastu sztuk, jakie niegdysiejszy autor komedii konwiktowych stworzył dla publicznego teatru. Starania króla, aby pozyskać jezuitę na dostawcę repertuaru, doszły do skutku i w ten sposób zaczęły się dzieje nowoczesnej polskiej komedii ${ }^{2}$. Znamienna okazała się także reakcja publiczności na widowisko - fala głosów, opinii, protestów.

${ }^{1}$ M. Klimowicz, Poczatki teatru stanisławowskiego (1765-1773), Warszawa 1965, s. 58; J. van der Meer, The Casanova Duel in "Monitor" or Foreigners in the Literary Field of the Stanislavian Era, „Wiek Oświecenia”, 30, 2014, s. 137-150.

2 Bohomolec uprawiał typ komedii dydaktycznej, którą rządziły między innymi: jasna tendencja ,ideowa”, imiona i nazwiska znaczące oraz binarne podziały postaci (młodzi - starzy, swoi - obcy, stołeczni - prowincjonalni, przy czym antytezy te mogły komplikować się i wchodzić w dodatkowe układy). Nie należy jednak sądzić, że publicystyczny kontekst i zawartość tych utworów umniejszały ich walory artystyczne. Ksiądz Bohomolec, naśladowca Moliera i tzw. autorów pomolierowskich (Philippe Destouches), ale też znawca włoskiej commedii dell'arte, był świetnym portrecistą obyczajów i języka (od niego wywodzi się linia komedii obyczajowej, która miała nawet swą warszawską odmianę). Za Molierem i teoretykami klasycyzmu Bohomolec uważał, że esencją komedii jest śmiech, humor, komizm, który następnie pobudza do refleksji (gdy do polskiej literatury dramatycznej weszły gatunki mieszane: dramy i tragikomedie, a także komedie , płaczliwe” - jezuita zrezygnował z pisania). Jego 
Drobnym tego przykładem jest list do redakcji „Monitora” napisany przez goszczącego przejazdem w stolicy szlachcica S. M. Muchowskiego ${ }^{3}$. Będąc w teatrze, na własnej skórze odczuł on działanie sztuki scenicznej, gdy część publiczności uznała go, ni mniej, ni więcej, za pobratymca jednej ze scenicznych postaci, Staruszkiewicza. Musiał chyłkiem wychodzić z Operalni, ukrywając pod wierzchnim okryciem kontusz, bez litości skompromitowany jako element sarmackiej ideologii. Bogu ducha winny przybysz z prowincji zrozumiał, że do teatru nie wchodzi się bezkarnie. Żadna książka ani gazetka pisana czy drukowana nie miały takiej siły mentalnego i emocjonalnego poruszania odbiorców, jak przedstawienie. Dodać jeszcze należy, że presja teatralna działała w dwie strony - oburzeni Sarmaci doprowadzili do tego, że w następnej sztuce Bohomolec ukazał Staruszkiewicza jako postać całkiem pozytywną i godną szacunku. Druga, po Natrętach Józefa Bielawskiego, premiera sceny narodowej dowiodła więc, że teatr jest miejscem gorącej dyskusji, iskra zapalona na scenie przenosi się natychmiast na widownię i z widowni na scenę, a w końcu, że loże - są także teatrem.

Pozostaje jeszcze jeden, na pozór błahy, wątek. W Małżeństwie z kalenda$r z a$-Polaków portrecie własnym - zyskali reprezentację członkowie wyjątkowej nacji osiadłej nad Wisłą. Mówiąc krótko, ledwo powstał polski teatr publiczny, a już pojawił się w nim polski Ormianin. Kupiec Anzelm Der Anzelmowicz to podobno zaszyfrowany wizerunek Symona Der Symonowicza, właściciela browarów, chlubiącego się również tytułem barona. Zanotował ten fakt Johann Heine, szpieg pracujący w Warszawie dla saskiego księcia Franciszka Ksawerego:

Wieczorem odbyła się polska komedia jak wskazuje załączony afisz, w której naród polski a szczególniej szlachta jest potraktowana w sposób niesłychany, zaś jej zwyczaje grubiańsko zganione. Na rozkaz króla napisał ją jezuita Bohomolec z tutejszej drukarni. Będzie też wydrukowana i oddana do publicznej sprzedaży. W komedii tej został także ośmieszony baron de Symonowicz, ponieważ nie chciał dać ani grosza w czasie interregnum. Nie przyznano mu również indygenatu, o który się starał w czasie ostatniego sejmu, choć zrobiono tę łaskę pozostałej trzodzie osłów ${ }^{4}$.

utwory bywają po prostu zabawne, nieodparcie śmieszne, świadcząc o opanowaniu techniki scenopisarskiej oraz znajomości wymogów teatru. Poza komediami, z których najwyżej dziś ceni się Pijaków (1767) oraz Autora komedii (1779), pisał również teksty do widowisk dramatyczno-muzycznych. Jego Nędza uszczęśliwiona (1770, wystawiona w 1778 z dodatkami Wojciecha Bogusławskiego i muzyką Macieja Kamieńskiego) to pierwsza polska opera. Zob. D. Ratajczakowa, Komedia oświeconych 1752-1795, Warszawa 1993, s. 78-94.

3 Drukowany między innymi w: S. Ozimek, Udziat ,,Monitora” w ksztaltowaniu Teatru Narodowego (1765-1785), Wrocław 1957, s. 205-210. Zob. też: J. van der Meer, The Muchowski-Letter and the Introduction to „Matżeństwo z kalendarza”. On Literary Production and Criticism in the First Years of the Stanistaw Age, ,Zeitschrift für Slawistik”, 44, 1999, 1, s. 93-102.

${ }^{4}$ [J. Heine], Teatr Narodowy 1765-1766. Raporty szpiega, przeł., red. M. Klimowicz, wstęp Z. Raszewski, Warszawa 1962, s. 17. 
Zdania te nie wywołały ze strony badaczy zbyt wielu komentarzy ani prób weryfikacji. Przyjęto je po prostu jako fakty. W monografiach teatru epoki stanisławowskiej, a także w studiach z dziejów Ormian w Polsce powtarza się słowo w słowo doniesienia Heinego ${ }^{5}$. Był to, owszem, człowiek dobrze poinformowany, ale też daleki od bezinteresownej ciekawości, gromadził i interpretował informacje na użytek politycznej intrygi. Jego wiadomość o nowej polskiej premierze jest zwyczajnie stronnicza, a być może już u samych źródeł obliczona na manipulację. Donosił nie tylko Heine, ale ktoś donosił Heinemu. Słowa przemierzały długą drogę z ust do ust, z ucha do ucha.

Zacznijmy od znanych informacji. Saski szpieg przyjaźnił się z Franciszkiem Bohomolcem. To sam autor Matżeństwa żalił mu się, że od dłuższego czasu król nie daje mu spokoju, zaprasza na kolacje i usilnie namawia do pisania dla teatru'. Może nawet król podsuwał pomysły przyszłych sztuk? ${ }^{7}$ To by wyjaśniało formułę: ,napisał na rozkaz”. Bohomolec od kilku lat nie uprawiał komediopisarstwa ani dydaktyki w konwikcie, był natomiast prefektem drukarni jezuickiej (stąd też wiadomość, że sztuka będzie wydrukowana) ${ }^{8}$. Wątpliwe jednak, by autor komedii chciał zejść do roli paszkwilanta i by obniżał wartość medium teatralnego, któremu poświęcił pół swojej kariery. Plotka o celowym ośmieszeniu Symonowicza musiała wyjść z ust kogoś innego, komu zależało na skompromitowaniu zarówno Bohomolca, jak i teatru jako narzędzia królewskiej propagandy ${ }^{9}$. Być może to sam Symonowicz skarżył się Heinemu na swoje kłopoty z uzyskaniem indygenatu - da się odczuć, że autor raportu darzy go litością i nie zalicza do ,pozostałej trzody osłów”. Zarówno notatka Heinego, jak i pierwsza w naszej narodowej komedii figura ormiańskiego kupca zasługują na to, by baczniej się im przypatrzeć.

Szpieg Wettynów od początku wypowiadał się o polskim teatrze z gruntu negatywnie, co wynikało z jego nastawienia do Stanisława Augusta oraz z podjętej służby. Wszystko, co robił wrogi Sasom król, podlegało krytyce Heinego, a więc również i teatr ${ }^{10}$. Aktorzy włoscy sprowadzeni do teatru królewskiego wyglądają

5 Zob. na przykład M. Klimowicz, Początki teatru, s. 210-211; P. Morawski, Oświecenie. Przedstawienia, Warszawa 2017, s. 149; K. Stopka, A. A. Zięba, A. Artwich, M. Agopsowicz, Ormiańska Warszawa, Warszawa 2012, s. 72-73.

${ }^{6}$ [J. Heine], Teatr Narodowy, s. 13.

7 S. Ozimek wysnuwa ten wniosek na podstawie dedykacji (Bohomolec dedykował Matżeństwo z kalendarza stolnikowi Augustowi Moszyńskiemu, bliskiemu współpracownikowi króla). S. Ozimek, Udziat „,Monitora”, s. 84-85.

${ }^{8}$ Istotnie wydano ją w Drukarni J. K. M. i Rzeczypospolitej, w Collegium Societatis Jesu w 1766 roku.

9 Kusi, by posądzić o to na przykład innego Ormianina, Józefa Epifaniusza Minasowicza, który blisko współpracował z Heinem, a także był pomocnikiem w redakcji „Monitora” - miał prawo czuć się zepchnięty na drugi tor zarówno w redakcji pisma, jak i w środowisku literackim, do którego aspirował.

${ }^{10}$ Warto podkreślić, że Heine miał ułatwiony dostęp do kulis teatralnych z powodów prawno-lokalowych. Przedstawienia dawano w pierwszym wolnostojącym budynku teatral- 
mu na „bandytów”, orkiestra to „zbieranina pozbawiona czucia i rytmu”, komedianci francuscy niczego nie potrafią, poza paplaniem, a aktorki polskiej komedii traktuje się epitetami typu „bezczelna flądra" ${ }^{11}$. O inaugurujących teatr polski Natrętach Heine pisze, że niektóre sceny przypominają mu dom publiczny ${ }^{12}$. $\mathrm{Z}$ czasem Heine zmienia zdanie w niektórych kwestiach (choćby o Włochach), ale też nie kryje, że interesuje go wszystko, co naraża króla na ,jeszcze większą nienawiść”13. „Spodziewają się [...], że w czasie sejmu będzie wielki napływ do teatru i że Król będzie wynoszony pod niebiosy za urządzenie tych rozrywek. Ale bardzo się mylą!” - czytamy w raporcie ${ }^{14}$. Teatr, na którym królowi tak bardzo zależało, jest więc $\mathrm{w}$ raportach Heinego z góry zdyskredytowany.

Nie dziwi wobec tego, że i okoliczności wystawienia Matżeństwa tajny sprawozdawca ukazuje jako szereg aktów nacisku i napaści: przymuszony Bohomolec, obrażona szlachta i ośmieszony Symonowicz (jedyny w całej tej historii dotknięty personalnie). Intrygujące jest, czy rzeczywiście Symonowicz naraził się królowi i czy jego historyczna postać przeziera zza sylwetki epizodycznego bohatera sztuki Bohomolca. Jeśli założymy, że do ośmieszenia warszawskiego kupca istotnie doszło, powstaje pytanie, jak to pogodzić z programem komedii klasycznej, która miała piętnować wady, a nie indywidualnych nosicieli wad. Heine nie wspomina o ormiańskich korzeniach Symonowicza (choć robią to wszyscy późniejsi edytorzy i komentatorzy raportów). Osobnym problemem jest więc to, jak postrzegano wówczas w Polsce ormiańskość i czy jako temat mogła się ona znaleźć w Matżeństwie z kalendarza, sztuce redefiniującej pojęcia rodzimości i cudzoziemszczyzny ${ }^{15}$.

nym w Polsce, zwanym potocznie Operalnią. Wzniesiona w 1725 roku i znacznie przebudowana w 1748 saska Operalnia wciąż należała do spadkobierców Augusta III, od których wynajmował ją Stanisław Poniatowski. Budynek popadł w ruinę po pierwszym rozbiorze i został wyburzony w 1772 roku. Zob. B. Król, Budynek Operalni saskiej w Warszawie, „Pamiętnik Teatralny", 1956, 4, s. 631-650.

11 [J. Heine], Teatr Narodowy, s. 8, 10.

12 „Na polskich komediach dają przeważnie intrygi miłosne, które dokładnie bywają odtwarzane za pomocą ruchów i słów, że tylko materaców brakuje. Tamże młode dziewczyny uczą się, czego jeszcze nie zaznały" (ibidem, s. 16). Niewiele lepiej wyraża się sprawozdawca o polskiej widowni, opisując ją jako natłoczonych krzykaczy i złodziei kieszonkowych.

13 Ibidem, s. 10.

14 Ibidem, s. 20.

15 Fabuła komedii jest prosta: szlachcic Staruszkiewicz wydaje za mąż córkę Elizę, wychowywaną od trzech lat w Warszawie u jego siostry Bywalskiej. Kandydatów jest dwóch: nieskazitelnego charakteru Niemiec Ernest, służący w polskim wojsku w randze pułkownika (i starający się o indygenat), oraz Polak Marnotrawski, szlachcic i ostatni hulaka (który starannie ukrywa przed ojcem Elizy, że jest bankrutem i wydrwigroszem). Staruszkiewicz skłania się właśnie ku niemu, bowiem nie ufa cudzoziemcom (ma wszystkich za „chłopów” i „heretyków”), liczy na pomnożenie majątku, a przede wszystkim konsultuje swoje plany $\mathrm{z}$ astrologicznym kompendium, tytułowym kalendarzem, który podpowiada datę ślubu. Ponieważ Eliza nie ma nic do powiedzenia, Ernest jest zbyt honorowy, by zdemaskować rywala, 
„Simon baron de Symonowicz, żonaty z Zofią Jędrzejowiczówną, właściciel Mściowa, Doraza i Kamieńca w województwie sandomierskiem. Otrzymał szlachectwo austriackie od cesarza Franciszka I w r. 1763, polskie w 1768. Prowadził handel winny" ${ }^{\prime 1}$. Jego nazwisko jest samo w sobie dowodem polonizacji rodziny, wskazuje na pochodzenie od trzonu Simon rozbudowanego pod wpływem polszczyzny (sufiksy). W źródłach nazwisko kupca występuje w kilku wariantach: Symonowicz, de Symonowicz, Dersymonowicz, Szymonowicz, a powodem tego była sprytna podmiana „ormiańskiej partykuły Der przed nazwiskiem, oznaczającej pochodzenie od kapłana, na francuską de, oznaczającą pochodzenie arystokratyczne”, do tego tytuł barona powstał „,na drodze swobodnej interpretacji terminu o tym samym brzmieniu, który w języku ormiańskim oznacza po prostu - pan" "17. Tak oto Symonowicz wykorzystał zjawisko międzyjęzykowej homonimii, by wzmocnić swe ambicje do tytułu szlacheckiego. Stosował też bardziej wymierne środki: kupował majątki. Symonowicz należał do tych bogatych i obrotnych kupców warszawskich, którzy stosunkowo szybko stali się ziemskimi posesjonatami. Zbudował sobie już na początku lat sześćdziesiątych na Solcu piękny pałacyk w neobarokowym stylu, otoczony ogrodem. Do tego parał się operacjami bankierskimi: pożyczaniem sum pieniężnych pod zastaw i na procent.

Właśnie w taki sposób kupiec Anzelm w komedii Bohomolca wchodzi w kontakt ze szlachcicem Marnotrawskim: „Dawałem mu w pieniądzach i towarach różnych"18 - a wszystko to pod gwarancją (,na fundamencie”) dobrej wioski, posagu narzeczonej, pensji u dworu tudzież spodziewanego zysku ze sprzedaży zboża w Gdańsku. Fakt, że kupiec Anzelm jest zarazem wierzycielem złotego młodzieńca, nie przesądza jeszcze, iż jego prototypem musiał być Symonowicz. Kilku jeszcze Ormian mieszkających w Warszawie przed nim i po nim obracało w ten sposób gotówką. Jakub Rafałowicz, brat finansisty Jędrzeja, trudnił się, obok handlu bławatnego, pożyczkami pod zastaw; pożyczali pieniądze: obrotna modystka, wdowa Urszula Łazarowiczowa i burmistrz (potem też prezydent) Starej Warszawy Grzegorz Łyszkiewicz, a nade wszystko jego syn, Maciej. Także słynny Paschalis Jakubowicz w czasach nieco późniejszych, bo w latach

a Staruszkiewicz jest istnym despotą - intryga przechodzi w ręce Agatki, obrotnej i zuchwałej służącej pani Bywalskiej. Ona zaprasza do domu wierzyciela Marnotrawskiego, kupca Anzelmowicza, i doprowadza do szczęśliwego zakończenia.

16 W. Smoleński, Mieszczaństwo warszawskie w końcu wieku XVIII, Warszawa 1917, s. 24. Obrót winem należał do specjalizacji ormiańskich, obok handlu towarami korzennymi i kolonialnymi, tkaninami, futrami, bronią, produktami żelaznymi i wreszcie tytoniem. Ormianie z południowo-wschodniej Polski zajmowali się w tym czasie handlem wołami, skórami i wyrobami skórzanymi oraz aprowizacją wojenną. Zob. F. Wasyl, Ormianie w przedautonomicznej Galicji. Studium demograficzno-historyczne, Kraków 2015, Studia Galicyjskie, 4.

17 K. Stopka, A. A. Zięba, A. Artwich, M. Agopsowicz, Ormiańska Warszawa, s. 72.

${ }_{18}$ F. Bohomolec, Matżeństwo z kalendarza, Kraków 2002 (na podstawie wydania Komedii w opracowaniu J. Kotta, Warszawa 1960, 2), s. 83. Z tego wydania pochodzą dalsze cytaty. 
siedemdziesiątych-osiemdziesiątych XVIII wieku, właściciel towarów tureckich i fabrykant pasów kontuszowych, „dawał panom towary na kredyt, służył im i pożyczką gotowizny" ", a nawet przejął za długi miasteczko Główno należące do jednego z dłużników. Byłby więc Anzelm stypizowanym odbiciem wielu ormiańskich kupców. Ormiańskie cechy, jeśli już ich szukać w bohaterze komedii, są przeważnie pozytywne, wręcz pochlebne dla tej nacji. Anzelm jest wcieleniem dyskrecji: w scenie ze Staruszkiewiczem potrafi tak prowadzić rozmowę, żeby nie zdradzać nazwisk, źródeł informacji, nikogo nie oczerniać. Do tego ma niemałą zdolność żywego i odpowiedniego reagowania na emocje interlokutora, na śmiech - wspólnym śmiechem, na gniew - stonowaniem i grzecznością. A gdy już sam straci kontrolę nad emocjami, bywa rozbrajająco szczery, nie przebierając w określeniach takich, jak „pogański syn” (o Marnotrawskim) czy „u kata”. Tropem wskazującym na ormiańskie tradycje może być również podejście Anzelma do ożenku. Staruszek zapewnia, że i on chętnie ożeniłby się z panną „dla stu tysięcy posagu". Niewinny żart nie jest znowu tak niedorzeczny, gdy wziąć pod uwagę politykę matrymonialną Ormian, dyktowaną przede wszystkim interesem rodzinnym i finansowym. Małżeństwa zawiązywano dla powiększenia spółek rodzinnych, wzmocnienia kapitału, dla zapewnienia ochrony sierotom i wdowom ${ }^{20}$.

Jeśli wierzyć Heinemu, Symonowicza zgubiło w oczach króla to, że ,nie chciał dać ani grosza w czasie interregnum”. Między 5 października 1763 (śmierć Augusta III) a 7 września 1764 roku (wybór nowego króla), gdy interreksem był prymas Władysław Aleksander Łubieński, obóz Czartoryskich zintensyfikował kampanię, która miała doprowadzić do elekcji Stanisława Poniatowskiego. Wymagało to niemałych nakładów finansowych (na przykład na kształtowanie opinii mas szlacheckich poprzez pismo zwane małym „Monitorem”), wymagało też sił militarnych ${ }^{21}$. W trakcie sejmu konwokacyjnego w Polsce rozpoczęła się wojna domowa między uchodzącą partią hetmańską a zwycięską Familią popieraną przez Rosjan. O wsparcie sprawy z jednej i z drugiej strony zabiegano u majętniejszych obywateli, w tym u Symonowicza, ale ten, „zamiast skorzystać

19 W. Smoleński, Mieszczaństwo warszawskie, s. 30.

${ }^{20} \mathrm{Na}$ przykład w 1781 roku w Mohylowie nad Dniestrem (wówczas mieście polskim) wdowa ormiańska ze Stambułu, Flora Piotrowiczowa, oddała rękę swej piętnastoletniej córki Reginy trzykrotnie starszemu kupcowi z Mohylowa Harutiunowi Szymonowiczowi. Przyszłością Reginy rozporządzono podobnie, jak rozporządza się losem Elizy w Matżeństwie z kalendarza. Różnica polega na tym, że ormiańska panna dostała za partnera dużo starszego od siebie wdowca, od którego następnie uciekła, decydując się na prawie dziesięcioletni proces rozwodowy. Zob. D. Jarząbek-Wasyl, F. Wasyl, O Ormiance, która nie chciała być żona dla męża. Proces o unieważnienie matżeństwa $w$ Mohylowie nad Dniestrem $w$ końcu XVIII wieku, „Przegląd Wschodni”, 14, 2017, 3 (55), s. 567-619.

${ }^{21}$ Zob. G. Szymborski, Wykorzystanie i kontrola wojska jako przedmiot gry politycznej i obrad sejmu konwokacyjnego w dobie bezkrólewia 1764 roku, „Acta Universitatis Lodziensis. Folia Historica”, 2017, 98, s. 58-59. Zob. też: W. Kaliszew ski, Kilka uwag o wierszach czasu ostatniego bezkrólewia, „Napis”, 1998, seria 4, s. 45-55. 
z propozycji i rzucić się w wir wielkiej polityki [...] odmówił”22. Czy odmówił ze skąpstwa, czy też z powodów politycznych - tego do końca nie wiadomo, przypuszcza się, że mógł żywić jakieś saskie sentymenty ${ }^{23}$. Pewne jest natomiast, że nim udało mu się posiąść szlachectwo polskie, otrzymał szlachectwo austriackie, przy czym wydarzyło się to na kilka miesięcy (10 czerwca 1763) przed śmiercią króla Augusta III (5 października 1763) ${ }^{24}$. Austria była zaś w trakcie interregnum po stronie hetmańskiej, a nawet okresowo zerwała kontakty dyplomatyczne z Rzeczpospolitą, jak reszta państw południowego przymierza ${ }^{25}$.

Być może zresztą niechęć Symonowicza do wydawania grosza na sprawy publiczne nie miała politycznego charakteru. A jeśli był on podejrzliwie traktowany w Warszawie - to raczej z powodu jego ambicji dołączenia do grupy nobilium. Okazało się, że Symonowicz szybciej dopiął swego za granicą (w Austrii wyniesienie do szlachectwa następowało na podstawie podania zatwierdzonego przez cesarza, za zasługi, choć praktycznie można było je kupić), w Polsce było to trudniejsze, bo ściśle reglamentowane i zależne od woli sejmu. Do tego paranie się handlem lub rzemiosłem uważano za zajęcie nieszlacheckie, a posiadanie ziemi - warunek nobilitacji - przez długi czas rezerwowano wyłącznie dla szlachty. Zmieniły tę sytuację dopiero reformy po sejmie koronacyjnym. Wówczas warszawski finansista Piotr Tepper otrzymał prawo kupowania placów w stolicy, a rok późnej prawo nabywania ziemi w ogóle. Na tytuł szlachecki czekał do $1790 \mathrm{roku}^{26}$. Sejm z 1790 roku nobilitował jeszcze jedenastu innych bankierów i fabrykantów ${ }^{27}$. O polską nobilitację już w 1765 roku zabiegał Symon Der Symonowicz, co przyniosło pozytywny rezultat dopiero po trzech latach, w 1768 roku $^{28}$. Konstytucją sejmową z tegoż roku Symonowicz został zwolniony od skartabellatu, czyli zastrzeżenia, że nowo nobilitowana rodzina do trzeciego pokolenia nie miała prawa piastowania urzędów oraz sprawowania funkcji poselskich. W dyplomie nobilitacyjnym, wystawionym w Warszawie dopiero sześć lat później (1 lutego 1774), którego oryginał szczęśliwie dochował się do naszych

${ }^{22}$ K. Stopka, A. A. Zięba, A. Artwich, M. Agopsowicz, Ormiańska Warszawa, s. 72.

${ }^{23}$ Ibidem.

${ }^{24}$ Der Adel von Galizien, Lodomerien und der Bukowina. J. Siebmacher's grosses und allgemeines Wappenbuch, 32, Nürnberg 1905, s. 123. Te i dalsze informacje o herbowych staraniach Symonowicza i losach jego rodziny, wraz z bibliograficznym zapleczem, pochodzą od Andrzeja A. Zięby, któremu dziękuję za uzupełnienia.

${ }^{25}$ E. Rostworowski, Wiedeńskie sperandy Poniatowskich i pierwszy rozbiór Polski, „Sobótka. Śląski Kwartalnik Historyczny”, 38, 1983, 4, s. 529.

${ }_{26}$ Zob. F. Wasyl, Ormianie w przedautonomicznej Galicji, s. 80. Tu także przypis 232.

27 T. Opas, Z problemów awansu społecznego mieszczan w XVII i XVIII wieku. O przenikaniu do stanu szlacheckiego i duchownego, „Przegląd Historyczny”, 65, 1974, 3, s. 467.

${ }_{28}$ Album armorum Nobilium Regni Poloniae XV-XVIII saec. Herby nobilitacji i indygenatów XV-XVIII w., wstęp, oprac. i edycja B. Trelińska, Lublin 2001, s. 578. Data dzienna nobilitacji nie jest znana, lecz została ona przyznana przed 9 marca, bo w tym dniu Symonowicz złożył przysięgę wymaganą przy przyjęciu nobilitacji. 
czasów, czytamy, że nobilitacja dotyczyła nie tylko jego, ale i dzieci „tak stanu duchownego, jak i świeckiego". Nadawca zdecydował przy tym, że nobilitowanych ,przy nadanym w roku 1763 od Franciszka pierwszego cesarza rzymskiego przez dyploma na szlachectwo imperii herbu [...] zostawiamy". Za badaczką polskich nobilitacji przytoczyć tu można opis tegoż herbu: „W polu błękitnym pas srebrny, na nim serce czerwone, od czoła dwa srebrne gołębie zwrócone ku sobie, trzymające w dziobach zielone gałązki oliwne, u podstawy dwie obrączki złote. Dwa hełmy z koronami. Klejnoty - od prawej orzeł srebrny bez korony ze skrzydłami rozpostartymi, [zwrócony] w lewo, od lewej gołąb, jak w godle, [zwrócony] w prawo. Labry - z prawej podbicie srebrne, pokrycie błękitne, z lewej podbicie srebrne, pokrycie czerwone"29.

Jeśli się uważniej przyjrzeć, dyskretna, zawoalowana aluzja do starań Symonowicza o awans tkwi w postaci Anzelma. Bohater komedii Bohomolca pozwala się wykorzystywać Marnotrawskiemu i wciąż pożycza mu gotówkę na bajeczną sumę stu tysięcy, ponieważ widzi w tym pewną szansę. Słowo „dwór”, powtarzane trzy razy, jest wymarzoną przestrzenią, a kluczem do niej - Marnotrawski: „Tak on i mnie ułowił. Rozumiałem, że on w samej rzeczy tak wzięty u dworu, jak on udawał. [...] Obiecywał mi złote góry. Na koniec, nie mogąc się doczekać satysfakcji, chciałem jego pensję u dworu aresztować, ale mnie tam wyśmiano i powiedziano, że on nie tylko nie należał do dworu, ale nawet na pokojach mu bywać zakazano dla jego złych i hultajskich postępków" (s. 83). Być może śmiech z Anzelma-Symonowicza był podwójny - z powodu utopionej w złym interesie fortuny i z powodu owych zamkniętych przed nim (a nie tylko przed Marnotrawskim) królewskich pokojów. Wszystko to są jednak domniemania, zainicjowane przez złośliwego saskiego szpiega. Ani skąpstwo Symonowicza (nie jest bardziej skąpy od Staruszkiewicza), ani jego apetyty na tytuł szlachecki, czy wreszcie niepowodzenia u dworu, nie zostały wprost stematyzowane w dramacie. Trudno się tu doszukać jawnej i płaskiej satyry, bezpośrednich deklaracji naprowadzających na tę, a nie inną osobę. Nazwisko Der Anzelmowicz nie pada ze sceny wówczas, gdy obecny jest „kupiec staruszek”, a dużo wcześniej - widzowie mogli dawno zapomnieć, jak zwie się ta postać ${ }^{30}$. Związki z Symonowiczem występują w tekście raczej jako lekkie sugestie, czytelne dla wąskiego grona wtajemniczonych. Najbardziej zaskakuje w całej tej historii, że postać Anzelma uległa tak prędko deszyfracji. Mieczysław Klimowicz uznał, że stało się to za sprawą interpretacji aktorskiej: „oczywiście publiczność operalni rozpoznała natychmiast w Malżeństwie z kalendarza Symonowicza, który był popularną postacią na terenie Warszawy, po sposobie gry aktora, naśladującego jego ruchy i głos"31.

\section{${ }^{29}$ Ibidem, s. 579.}

${ }^{30}$ Anzelmowicza sprowadza (w akcie III) subretka Agata, która mówi też przy końcu aktu I: „Ma tu być niejakiś kupiec Der Anzelmowicz, u którego Marnotrawski najwięcej długów zaciągną̧" (s. 40).

${ }^{31}$ M. Klimowicz, Początki teatru, s. 211. 
Tu powstaje osobny problem. Taktyka naśladowania na scenie realnych osób, zwłaszcza na początku istnienia teatru publicznego, mogła się okazać nader niebezpieczna i obosieczna. Dawała argument ludziom nieprzekonanym do społeczno-moralnej użyteczności teatru. Pismo „Monitor”, w którym apologia teatru zajmowała poczesne miejsce, praktykowało zasadę: „W szczególności nikomu nie łaję, / czołem biję osobom, ganię obyczaje" "32. To samo miało obowiązywać w teatrze. „«Monitor» ani komedia polska okresu Oświecenia nie zdobędzie się na imienną krytykę. Była to zasada silna, sankcjonowana prawnie. [...] W trzecim punkcie przepisów dla teatrów marszałka [Stanisława] Lubomirskiego czytamy: «Reprezentacje by nie były gorszące, tangentes statum religionem, lub satyryczne dla osób»" ${ }^{\prime 3}$. Czy wobec tego król - dla niewinnej zemsty na krnąbrnym Ormianinie - łamałby zasady estetyczne oraz obyczajowe i narażał przyszłość całej instytucji? Czy też status Symonowicza był na tyle niski, że można było go uczynić przedmiotem paszkwilu? Wyjaśniałoby to, dlaczego sam poszkodowany nie protestował, nie wnosił skarg. Niewykluczone też, że po prostu o niczym nie wiedział. Kusi jednak, by wyobrazić sobie alternatywne rozwiązanie. Kupiec usłyszał o krążących plotkach, zasiadł w kantorze swej winiarni i... zacierał ręce, bo na pewno przyczyniło mu to nowej klienteli, zwiększając popularność tak osoby, jak i firmy. W końcu nawet Paschalis Jakubowicz rozpuszczał w prasie fałszywe pogłoski o swych towarach, żeby potem zaprzeczać i zwiększyć ich cenę rynkową ${ }^{34}$.

Trudno dla większości tych hipotez zebrać materiał dowodowy, niemniej jedno wydaje się pewne: ani Bohomolec, ani jego możny zleceniodawca nie zamierzali obrażać czy ośmieszać Ormian. A to dlatego, że przedstawiciele tej wspólnoty, w większości zintegrowani w społeczeństwie polskim i lojalni wobec Polski, oddawali wielorakie usługi królowi, miastu, kulturze i literaturze. Choć w samej Warszawie Ormianie stanowili jedną z najmniejszych grup etnicznych, wyróżniali się prężnością i aktywnością zawodową w wielu dziedzinach oraz talentem szybkiej adaptacji w nowym otoczeniu społecznym. Już w drugim pokoleniu osiadli w mieście przybysze ze Wschodu lub Południa całkowicie wchłonęli „treść narodową" ${ }^{35}$. Historycy skrupulatnie dowiedli, że Ormianie w końcu XVIII wieku pełnili odpowiedzialne funkcje publiczne w administracji państwowej i samorządzie miejskim, Kościele, sądownictwie, edukacji, prasie, konfraterniach kupieckich; tworzyli pierwsze domy bankierskie i zakładali manufaktury (tytoniowe, włókiennicze, papiernicze), reformowali polskie szkoły, tłumaczyli literaturę z obcych języków, kierowali nowo utworzoną pocztą, prowadzili praktykę lekarską i aptekarską, byli wśród nich artyści malarze,

${ }^{32}$ Cyt. za: S. Ozimek, Udziat „,Monitora”, s. 31.

33 Ibidem.

${ }^{34}$ Zob. K. Stopka, A. A. Zięba, A. Artwich, M. Agopsowicz, Ormiańska Warszawa, s. 45 .

${ }^{35}$ W. Smoleński, Mieszczaństwo warszawskie, s. 22. 
a nawet jeden marszand sztuki. Nie wchodząc w szczegóły, przypomnijmy tylko, że urząd prezydenta Starej Warszawy wielokrotnie dzierżyli właśnie Ormianie. W XVIII wieku byli oni tą grupą, która najżywotniej włączyła się w proces rozszerzania granic stanowych - mobilni pod każdym względem przechodzili z warstwy mieszczańskiej do szlacheckiej, ale też z mieszczan przeobrażali się w urzędników, inteligencję, wykonawców wolnych zawodów.

Synowie warszawskich mieszczan z rodów ormiańskich przebywali również w bliskim otoczeniu króla Stanisława Augusta, służąc mu radą, wiedzą i pożyczkami, za co dostawali różnorakie tytuły, na ogół honorowe. Dość powiedzieć, że lekarzami i konsyliarzami króla byli: Jakub Minasowicz (od 1771), Józef Kazimierz Łukaszewicz (od 1789) i Jan Jaśkiewicz; kapelanem nadwornym - Kajetan Muratowicz, przyjacielem i uczestnikiem obiadów czwartkowych - ks. Grzegorz Piramowicz, cenionym przez króla kaznodzieją był ksiądz (później biskup) Grzegorz Zachariaszewicz, zaś Jan Jędrzejowicz - sekretarzem JKMci i asesorem sądów nadwornych. „Powszechnie są znane fakty wspomagania szkatuły królewskiej Stanisława Augusta przez kupców i bankierów ormiańskich" ${ }^{36}$. W grę wchodziły pożyczki, ale i wspólne interesy. Jędrzej Rafałowicz był udziałowcem manufaktur braci Poniatowskich, król ciekawym okiem spoglądał też na persjarnię Paschalisa Jakubowicza, a nawet złożył w niej wizytę. Synowie Paschalisa wzięli za żony panny z rodziny Franciszka Ryxa, doradcy królewskiego i specjalnego intendenta teatru $w$ latach siedemdziesiątych i osiemdziesiątych. Wszystko to wydarzyło się znacznie później niż premiera Matżeństwa z kalendarza, nie ma jednak powodu sądzić, że monarcha był wcześniej uprzedzony do Ormian jako takich. Na sejmie koronacyjnym w 1764 roku wśród uhonorowanych (zwyczajowo, jak i przy poprzednich koronacjach) specjalnym tytułem eques auratus wyróżniono między innymi burmistrza Pawła Andrychowicza ${ }^{37}$.

Również ksiądz Bohomolec stale obracał się wśród Ormian jako towarzyszy stanu duchownego, literatów (Józef Epifani Minasowicz), wreszcie kompanów i wspólników biesiad. Serdeczne więzi połączyły jezuitę po pierwszym rozbiorze z kupcem Grzegorzem Łyszkiewiczem, z którym ,wysuszał” ,przy miłych dyskursach niejedną flaszkę z zasobnej piwniczki" ${ }^{38}$. Grzegorz Rafał Łyszkiewicz, poza tym, że pełnił najważniejsze funkcje w magistracie warszawskim, miał dom bankierski i zarabiał sporo na procentach z pożyczek ${ }^{39}$. Drzwi domu nr 63 przy Rynku Starej Warszawy były dla Bohomolca otwarte, podobnie jak spiżarnia i piwnica $\mathrm{z}$ winem; pod wpływem biesiad u Łyszkiewiczów autor Matżeństwa z kalendarza napisał około 1779 roku sławną pieśń Kurdesz nad kurdeszami ${ }^{40}$.

${ }^{36}$ E. Tryjarski, Ormianie w Warszawie. Materiały do dziejów, Kraków 2001, s. 14.

37 T. Opas, Z problemów awansu, s. 468

${ }^{38}$ S. Ozimek, Udziat „Monitora”, s. 93.

39 K. Stopka, A. A. Zięba, A. Artwich, M. Agopsowicz, Ormiańska Warszawa, s. 39.

${ }^{40}$ Zob. szerzej: T. Mikulski, ,Kurdesz nad kurdeszami”. Zagadnienie tekstu i autorstwa, „Pamiętnik Literacki”, 50, 1959, 1, s. 1-49. 
I znów trudno wyrokować, na ile te przyjaźnie i kontakty były żywotne kilkanaście lat wcześniej, co nie zmienia faktu, że w sztuce, w której przedstawiciel konserwatywnej szlachty oskarża o wszelkie zło cudzoziemców i pod niebiosa chwali „swojskość”, Ormianie nie są atakowani, ponieważ... nie uznaje się ich za cudzoziemców. W oczach Staruszkiewicza obcymi są oficer Ernest, szlachcic pochodzenia niemieckiego, oraz jego sługa Johan - natomiast pochodzenie kupca Anzelma wydaje się przezroczyste. Żaden z bohaterów, ze Staruszkiewiczem włącznie, nie czyni aluzji do jego etnicznego rodowodu. I są po temu trzy powody. Pierwszy wynika z pragmatycznego stosunku Staruszkiewicza do ludzi, o czym świadczy następujący fragment rozmowy:

BYWALSKA Masz waszmość pan imć pana Ernesta, tak godnego kawalera. STARUSZKIEWICZ Pewnie, że za niego wydałbym [córkę], kocham go, ale to nieszczęście, że cudzoziemiec.

BYWALSKA Co to ma przeszkadzać? Tyle godnych dam polskich poszło za cudzoziemców!

STARUSZKIEWICZ Dlatego też i ginie nasza Polska.

BYWALSKA Za co ginie? I owszem, jeśli kiedy, tedy teraz mamy nadzieję, że Polska głowę podniesie.

STARUSZKIEWICZ Prawda, że teraz podniosłaby, gdyby tych cudzoziemców nie było.

BYWALSKA I owszem, do tego trzeba cudzoziemców, żeby się rzemiosła mnożyły, żeby się nowe manufaktury zakładały, żeby handel zakwitnął, żeby ekonomia była polepszona.

STARUSZKIEWICZ Hola! Hola! Na to nie ma zgody. Ja bym ich wszystkich powypędzał.

BYWALSKA Piękne zdanie! Waszmość pan Żydów utrzymujesz, a chrześcijan, ludzi uczciwych i tak nam potrzebnych, nie chcesz cierpieć.

STARUSZKIEWICZ Żydów, Żydów! Co inszego Żydzi. My od nich pieniążki mamy. Oto i teraz mój arendarz, pan Szmujski, postąpił mi z karczmy arendy dwieście dziesięć złotych, a przedtem tylko dwieście miałem.

BYWALSKA Alboż to mało nam pożytku czynią cudzoziemcy?

STARUSZKIEWICZ Ja od nich i szeląga nie widziałem. (s. 90-91)

W systemie myślowym Staruszkiewicza ci, z którymi wszedł w symbiozę gospodarczą, nie są już obcy - to przypadek Żydów, których Staruszkiewicz traktuje jak „swoich”, choć jednak niższych, sobie poddanych. Żydzi nie są obcy, to „Żydzi pańscy”. Wydawałoby się, że podobna, protekcjonalna akceptacja spotkała Ormian, ale to tylko pozór. Drugi i rzeczywisty powód niewidoczności ormiańskich (to znaczy nieswojskich) rysów Anzelma wynika z autentycznej integracji tej grupy, zmieszania żywiołów polskiego i ormiańskiego na zasadzie równorzędności. Ormianie stali się swoi, wnikając w społeczność polską pod każdym względem: języka, ubioru, obyczaju (w końcu to oni zaopatrywali 
szlachtę w stroje wschodnie i broń), niektórzy zmienili nawet obrządek z ormiańskokatolickiego na łaciński. Oczywiście nadal pielęgnowali cechy i obyczaje wyróżniające ich na tle innych nacji (spółki rodzinne, praktyki religijne i pobożność, małżeństwa endogamiczne), nie mieli jednak oporu przed włączaniem się w życie zbiorowości, do której trafili. Szybko odnosząc sukcesy, raczej unikali epatowania bogactwem lub rangą, co sprawiło, że nie przylgnęły do nich negatywne stereotypy. Co ciekawe, cnoty społeczne, które - w opozycji do zepsutego dworu i magnaterii - wymieniał Muchowski w liście do „Monitora”" ${ }^{41}$, doskonale odnosiły się do przeciętnych Ormian polskich: dzielnych zarówno „in sobria vita”, jak i ,in zelo fidei orthodoxae”. Ormianie rychło podzielili się i rozczłonkowali na frakcje, jak sami Polacy; w połowie XVIII wieku część z nich opowiedziała się za Sasami i partią hetmańską, część przystąpiła do partii postępowej. Jedyne, co wyróżniało ich jeszcze od reszty społeczeństwa, to niechętne podejmowanie kariery wojskowej. Woleli pracować i handlować, niż walczyćc ${ }^{42}$.

Nacja obdarzona talentami lingwistycznymi i komunikacyjnymi szybko przyswajała sobie zasady miejscowe, stopniowo wprowadzając do własnych tradycji nowe elementy. Integracja niosła za sobą zacieranie różnic i tworzenie nowej jakości. Nie było to zjawisko bezproblemowe, skoro w 1780 roku tylko pięć rodzin ormiańskich pojawiało się na tradycyjnych nabożeństwach w grabarze, celebrowanych w jednym z warszawskich kościołów klasztornych ${ }^{43}$. Reszta rozproszyła się wokół Warszawy lub przeszła do duszpasterstwa łacińskiego.

Zbliżenie ułatwiała więc wspólna religia. I to trzeci powód traktowania Ormian jak rodzimych obywateli - w końcu niechęć szlachty do cudzoziemców brała się w dużej mierze z identyfikowania ich z ,innowiercami”. W ogniu niepokojów politycznych oraz agitacji kontrreformacyjnej szlachta wyzbyła się resztek tolerancji i gościnności dla obcych. Powszechnie wiadomo, że sprawa dysydentów była też narzędziem nacisku stosowanym w Warszawie przez dwory pruski i rosyjski - opór budził więc sam fakt „reżyserowania” polskiej polityki wewnętrznej przez obce mocarstwa.

Dotychczasowe rozważania można by podsumować następująco. Bliska zażyłość z Ormianami, którzy uważali się za Polaków i tak byli odbierani, przepisy komedii, a wreszcie interes samych widowisk wskazywałyby na to, że postać Anzelma w Matżeństwie z kalendarza nie była zamówionym paszkwilem na cudzoziemskich kupców, ani nawet - na samego Ormianina Symonowicza. Co do

41 S. Ozimek, Udziat „Monitora”, s. 210.

${ }^{42}$ Zmieniło się to jednak w czasie rozbiorów, a warto podkreślić, że dwaj synowie Symonowicza zostali właśnie wojskowymi. Teodor służył w artylerii koronnej, a Baltazar był chorążym artylerii litewskiej. Trzeci syn, Feliks, został kanonikiem inflanckim i proboszczem w Garwolinie, a czwarty, Marcin, ,prawa spadkowe po rodzicach sprzedał Niedziałkowskiemu za 1,000 dukatów". W. Smoleński, Mieszczaństwo warszawskie, s. 24.

${ }^{43}$ To opinia Sadoka Barącza, cyt. za: K. Stopka, A. A. Zięba, A. Artwich, M. Agopsowicz, Ormiańska Warszawa, s. 34. 
pierwszego, żywioł ormiański tak mocno splótł się z polskim, iż nie mógł służyć za znak cudzoziemszczyzny. Ormiański rodowód Rafałowiczów, Jakubowiczów, Jędrzejewiczów i kilkudziesięciu innych rodów warszawskich idealnie wspierał główną myśl obozu postępowego, iż Polska potrzebuje przedsiębiorczych cudzoziemców, z których w krótkim czasie formuje lojalnych obywateli. Aż dziw bierze, dlaczego Bohomolec nie użył tego argumentu w sprawie Ernesta. Mógł go zrobić kawalerem ormiańskim z warszawskiej familii, a tymczasem zdecydował się na niemieckiego katolika w polskiej służbie wojskowej. Stało się tak prawdopodobnie dlatego, że kawaler do ręki panny Elizy musiał być szlachcicem-rycerzem, a Ormianie wciąż byli jednak przypisani do stanu mieszczańskiego i od cnót wojennych stronili ${ }^{44}$.

Co do drugiej sprawy, to znaczy satyry osobistej, jeśli są w Matżeństwie z kalendarza aluzje do historycznego Symonowicza, pozostają nadzwyczaj dyskretne i ukryte. Być może odtwórca roli dodał $\mathrm{z}$ własnej inicjatywy jakieś elementy charakterystyczne dla tej osoby, choć takie postępowanie naruszało regulamin ${ }^{45}$.

Skomplikowane i kapryśne bywają prawa teatralnej recepcji. Historia pokazuje, że często zupełnie niewinne fragmenty, słowa, sceny wywołują niekontrolowany odzew na widowni, zaskakując samych twórców. W dobie potargowickiej dość było Polakom usłyszeć ze sceny imię „Szczęsny”, by zaczęła się wrzawa na widowni. W 1838 roku wystarczyło, że jeden z aktorów dodał do fikcyjnej wzmianki o kantorze realne nazwisko warszawskiego lichwiarza Dawidsona, a inny Dawison (młody i zdolny aktor występujący w rolach amantów) był już skompromitowany i ośmieszony. Czy tu nastąpiło coś podobnego? Podejrzewam, że zadziałała ukierunkowana na wychwytywanie takich ,smaczków” percepcja widzów - kto wie, czy sam Heine nie był wybitnym łowcą tego rodzaju pikanterii scenicznych. Sam zresztą przyznaje w raportach, że komedie przewidziane ku naprawie obyczajów, wyposażone w ładunek publicystyczno-humorystyczny (ukazujące współczesne charaktery, pasje i namiętności w tonie ironii i satyry) bywają odbierane w sposób udosłowniony: „Można to jednak łatwo odczytać jako paszkwil na wszystkie tutejsze urządzenia krajowe i zwyczaje szlachty"46. Sens sztuki rodził się na widowni i ulegał niekiedy zupełnemu przenicowaniu.

${ }^{44}$ Wspomnianego na początku spektatora Muchowskiego nic tak nie obraziło w komedii, jak fakt, że Staruszkiewicz z lęku przed gotowym go pobić Marnotrawskim przewraca się na scenie i zapomina zrobić użytek z szabli. „Co jest nieznośną ujmą renomenu Polaków, którzy dosyć byli straszni i sławni, [...] gdyby nie polska szabla, pogubiliby cudzoziemcy szpady". S. Ozimek, Udziat „Monitora”, s. 206-207.

45 „Ktoby się ważył podczas repetycyi lub komedii przydawać, uymować lub odmieniać słowa, albo też gesta, które nie są podczas repetycyi aprobowane, będzie karanym wytrąceniem z pensji miesięcznej cz. złł jeden”. Regulament dla aktorek y aktorów polskich, w: K. Wierzbicka, Źródta do historii teatru warszawskiego od roku 1762 do roku 1833, 1, Czasy stanisławowskie, Wrocław 1951, s. 101.

${ }^{46}$ [J. Heine], Teatr Narodowy, s. 15. 
Podejrzenie przyjęte przez wąską grupkę (tych, którzy potrafili rozpoznać Symonowicza lub którym zależało na przypisaniu komedii cech paszkwilu) jak stugębna plotka rozlało się po premierze i stało... faktem.

Nie jest w końcu najważniejsze, czy Anzelm odzwierciedla realne rysy Ormianina i kupca, lecz jak ta figura ma się do reszty świata dramatycznego. Anzelm jest, wypisz wymaluj, drugim Staruszkiewiczem. Scena ich spotkania w komedii (jedyna zresztą, w której pojawia się kupiec) zadziwia właśnie jako konstrukcja sobowtórowa. Jednego i drugiego bohatera subretka Agata nazywa „dziadem”niekoniecznie $\mathrm{w}$ sensie pejoratywnym, raczej $\mathrm{w}$ znaczeniu podeszłego wieku i ograniczonych sił. Do obu pasuje etykieta: „choć jest prostaczek, ale ma dobre pieniądze". Obaj świetnie orientują się w cenach i cyfrach; wbrew pozorom zacofany Staruszkiewicz, amator sarmackiego kalendarza, całkiem trzeźwo robi interesy, używa też innych książek poza osławionym kalendarzem, w tym księgi rachunkowej. Obaj kamuflują swoje zamiary: Anzelm nie zdradza się z początku, w jakim celu przychodzi, a Staruszkiewicz udaje, że nie jest Staruszkiewiczem. Nieufność jednego dorównuje podejrzliwości drugiego. Cały dowcip w tym, że bohaterowie nie tylko nie znają się nawzajem, lecz nie znają samych siebie. Patrząc w lustrzane odbicie, jakim jest interlokutor, powinni dostrzec oszukaną, zacietrzewioną, na swój sposób bezsilną, choć żądną władzy starość. Tymczasem - pozostają ślepi na swoje wady. Kupiec Anzelm pojawia się więc w Matżeństwie z kalendarza dla wzmocnienia komizmu (i krytyki postawy) Staruszkiewicza oraz jako przebłysk jego potencjalnej autorefleksji. Byłaby to nie tylko epizodyczna scenka obyczajowa z „merkatorem”, ale też samodzielna scena rozpoznania (anagnorisis). Nieskutecznego rozpoznania, dodajmy, bo choć Staruszkiewicz dowiaduje się o nieuczciwości przyszłego zięcia, nie dostrzega błędów w sobie ani nie zastanawia się nad fundamentami własnych przekonań i decyzji. Wykrzykuje wprawdzie triumfalnie: „Jam jest sam prawdziwy Staruszkiewicz, którego waszmość pan prostaczkiem nazywasz" - wystarczy jednak odwrócić szyk słów, by objawił się ich właściwy sens: ,ja Staruszkiewicz jestem prawdziwym prostaczkiem”.

A co z Anzelmem?

Gdyby nie on, małżeństwo z kalendarza doszłoby to skutku, Marnotrawski sprzeniewierzyłby fortunę Staruszkiewiczów, Ernest poszedłby zapewne z rozpaczy na wojnę i zginął, a Agatka została starą panną na wiecznej służbie. Tylko Anzelm miałby swoje tysiące z powrotem. Pora definitywnie rozprawić się z raportem Heinego. To nie teatr ośmieszył ormiańskiego kupca (jak insynuuje Heine), a ormiański kupiec ocalił teatralne persony. Ironią losu (czy też przeznaczeniem figur epizodyczno-komicznych) jest to, że wybawiciel familii Staruszkiewiczów odchodzi w kaskadzie śmiechu na widowni - sromotnie oszukany. Mądry Ormianin po szkodzie ${ }^{47}$.

${ }^{47}$ Nie od rzeczy będzie tu jednak dodać, że progenitura warszawskiego kupca bez reszty weszła w szlachecką społeczność. Córkę wydał Symonowicz za Józefa Niedziałkowskiego 


\section{Aneks}

Franciszek Bohomolec, Matżéstwo z kalendarza, akt III, scena 3 (s. 80-87)

Staruszkiewicz, Anzelm.

ANZELM Kłaniam waszmość panu.

STARUSZKIEWICZ Najniższy sługa. A do kogo to?

ANZELM Czy tu mieszka imć pan Staruszkiewicz?

STARUSZKIEWICZ Tu. (potem mówi do siebie) Nie zna mię, nie wydam się. [(do Anzelma)]. Masz waszmość pan interes do niego?

ANZELM Znajdzie się.

STARUSZKIEWICZ Możesz waszmość pan mnie się zwierzyć, bo jego wszystkie interesa przeze mnie przechodzą. On beze mnie nic nie czyni, a co ja postanowię, to i on przyjmuje.

ANZELM Tym lepiej.

STARUSZKIEWICZ Słucham tedy.

ANZELM Dowiedziałem się, że imć pan Staruszkiewicz wydał swą córkę za pana Marnotrawskiego.

STARUSZKIEWICZ Abo co? Abo i waszmość pan jej chciałeś? Cha, cha!

ANZELM Cha, cha, cha! Czemu nie, wziąłbym, gdyby mi ją dano, bo słyszałem, że ma posagu na sto tysięcy. Powabna taka dama.

STARUSZKIEWICZ Hola, hola, nie tak wiele. Wiele by to było na imć pana Staruszkiewicza.

ANZELM Mnie mówiono, że imć pan Staruszkiewicz, choć jest prostaczek, ale ma dobre pieniądze.

STARUSZKIEWICZ Prostaczek? Któż to waszmość panu mówił?

ANZELM Ludzie. Ale wiele przecie tego posagu?

STARUSZKIEWICZ Będzie ze wszytkim koło dwudziestu tysięcy.

ANZELM Tylko?

STARUSZKIEWICZ Więcej nie będzie.

ANZELM Zginąłem. Zgubił mię ten hultaj Marnotrawski.

STARUSZKIEWICZ Albo co?

ANZELM To ja i piątej części długu nie odbiorę.

(1736-1829), starostę długołęckiego w powiecie kutnowskim, który w 1788 roku przejął pałacyk na Solcu (zapewne po śmierci teścia), by zaraz potem sprzedać go innej rodzinie ormiańskiej, Łazarowiczom (T. S. Jaroszewski, The Book of Warsaw Palaces, Warszawa 1985, s. 149). Jeden z synów Symonowicza, Feliks, obrał stan duchowny, był kanonikiem inflanckim i proboszczem w Garwolinie, gdzie pobudował kościół (1772). Dwaj pozostali, jak już wspominano, zostali oficerami, Baltazar - w artylerii litewskiej, Teodor - w artylerii koronnej. Ten ostatni żenił się kolejno z siostrami Straszewskimi, Kunegundą i Konstancją, pochodzącymi z rodziny właścicieli znacznych dóbr ziemskich w powiecie krakowskim (ich brat, Florian Straszewski, był współtwórcą Plant w Krakowie). Z kolei syn Teodora, Kazimierz, dostał za żonę córkę Stanisława Wielogłowskiego, stolnika rawsko-mazowieckiego, Teklę. 
STARUSZKIEWICZ Jakiego długu?

ANZELM Winien mi więcej sta tysięcy.

STARUSZKIEWICZ Kto? Marnotrawski?

ANZELM Ten filut bezbożny!

STARUSZKIEWICZ Jak to? Imć pan Marnotrawski filut?

ANZELM Filut nad filutami.

STARUSZKIEWICZ Ostrożnie proszę gadać o tym kawalerze, który tak jest wzięty u dworu!

ANZELM Cha, cha, cha! Czy i waszmość panu on to wyperswadował? Tak on i mnie ułowił. Rozumiałem, że on w samej rzeczy tak wzięty u dworu, jak on udawał. Dawałem mu i w pieniądzach, i w towarach różnych. Obiecywał mi złote góry. $\mathrm{Na}$ koniec, nie mogąc się doczekać satysfakcji, chciałem jego pensję u dworu aresztować, ale mnie tam wyśmiano i powiedziano, że on nie tylko nie należał do dworu, ale nawet na pokojach mu bywać zakazano dla jego złych i hultajskich postępków.

STARUSZKIEWICZ Czy mnie się śni, czy waszmość pan żartujesz?

ANZELM Mnie się płakać chce, nie żartować! Mówił mi, pogański syn, że jutro ma wypłacić posagowymi pieniędzmi sto tysięcy. Tymczasem mnie ostrzeżono, że insi kredytorowie na też pieniądze czuwają. Za czym przybiegłem tu $\mathrm{z}$ aresztem na posag.

STARUSZKIEWICZ Ale to grubo jest, mospanie, takiemu człekowi aresztować sumy, który ma wioskę, starostwo...

ANZELM Jaką, u kata, wioskę? Którą przy mnie samym przedał? Ten człek nic a nic nie ma, goły jak palec.

STARUSZKIEWICZ [do siebie mówi] Coś mi serce poziewa. [(do Anzel$m a)$ ] Ale wziął przecież starostwo...

ANZELM Cha, cha, cha! Tak on i mnie oszukiwał. Jemu by miano dać starostwo? Ja najlepiej się o nim informuję codziennie, bo mi chodzi o rzecz. Patrz waszmość, co mi winien. Oto obligi.

STARUSZKIEWICZ [do siebie mówi] Niedobry coś wiatr od tych papierów zawiewa. [(do Anzelma)]. Ale... komisarz jego pisał, iż mu wiezie pięć tysięcy czerwonych złotych.

ANZELM Cha, cha, cha! Pewnie ze Gdańska za zboże?

STARUSZKIEWICZ Tak jest.

ANZELM Słowo w słowo tak mię oszukiwał. Pokazywał mi jeszcze obligi od różnych panów...

STARUSZKIEWICZ Albo i to nieprawda?

ANZELM Wszystko to kłamstwo, fałsz, filutowstwo.

STARUSZKIEWICZ Dlaboga, znałem jego ojca! Zostawił mu dobrą wioskę i pieniążki nieszpetne.

ANZELM I ja na tym fundamencie mu pożyczałem, ale to wszystko karty i panienki modne pożarły. Lecz ja się bawię z waszmość panem, a czasu nie mam. Chciałbym ten areszt oddać imć panu Staruszkiewiczowi przynamnie na te dwadzieścia tysięcy posagu. Lepiej i to niż nic. 
STARUSZKIEWICZ Jak waszmość pan możesz kłaść areszt na posag, kiedy jeszcze ślubu Marnotrawski nie wziął z Elizą!

ANZELM Jak to nie wziął? On pisał do mnie, że już po ślubie, tylko że imć pan Staruszkiewicz nie chce mu zaraz tego posagu oddawać. Oto i bilet jego.

STARUSZKIEWICZ Obaczmy, co w tym bilecie... Charakter jego, jego własnych charakter! Czytam: ,żem podług słowa nie uspokoił waszmość pana, winien jest temu imć pan Staruszkiewicz, który oddawszy mi córkę, odkłada i przewleka oddanie mi posagowych stu tysięcy. Ale musi mi dziś oddać ten trup przebrzydły, ja mu i z gardła wydrę te pieniądze. Proszę o krótką cierpliwość”. Piękny ma styl: „Ja mu i z gardła wydrę”! „Wydrę”! „Z gardła wydrę”! Co za bezbożny człowiek! Kto by się spodziewał!

ANZELM Więc waszmość pan mówisz, że jeszcze nie po ślubie?

STARUSZKIEWICZ I nigdy nie będzie po ślubie. Co to za człowiek!

ANZELM Zmiłuj się, nie mów waszmość pan imć panu Staruszkiewiczowi o tym, cośmy mówili. Bo on może nie wydać córki za niego, a ja pieniądze stracę. Jam wszystko rozumiał, że rzecz już zakończona.

STARUSZKIEWICZ Ani waszmość pan pieniędzy, ani on córki mojej niech się nie spodziewa.

ANZELM Wszak nie waszmość pana, ale pana Staruszkiewicza córkę miał pojąć.

STARUSZKIEWICZ Jam jest sam prawdziwy Staruszkiewicz, którego waszmość pan prostaczkiem nazywasz.

ANZELM Nie ja... jam rozumiał...

STARUSZKIEWICZ Dziękuję waszmość panu za tę informacją wielce mi potrzebną. Kłaniam. Idź sobie szczęśliwie.

ANZELM Ale jakże? Ja dla wszystkiego ten areszt tu zostawuję.

STARUSZKIEWICZ Ten areszt ani waszmość panu pomoże, ani mnie zaszkodzi. Bądź waszmość pan zdrów! Kłaniam.

ANZELM Szkoda, żem się wcześnie wygadał. Zginąłem, już nie ma i nadziei.

[Odchodzi].

\section{Bibliografia}

\section{Źródła}

Bohomolec F., Matzeństwo z kalendarza, Kraków 2002

[Heine J.], Teatr Narodowy 1765-1766. Raporty szpiega, przeł., red. M. Klimowicz, wstęp Z. Raszewski, Warszawa 1962

Wierzbicka K., Źródła do historii teatru warszawskiego od roku 1762 do roku 1833, 1, Czasy stanistawowskie, Wrocław 1951

\section{Opracowania}

Album armorum Nobilium Regni Poloniae XV-XVIII saec. Herby nobilitacji i indygenatów XV-XVIII w., wstęp, oprac. i edycja B. Trelińska, Lublin 2001 
Der Adel von Galizien, Lodomerien und der Bukowina. J. Siebmacher's grosses und allgemeines Wappenbuch, 32, Nürnberg 1905

Jaroszewski T. S., The Book of Warsaw Palaces, Warszawa 1985

Jarząbek-Wasyl D., Wasyl F., O Ormiance, która nie chciała być żona dla męża. Proces o unieważnienie matżeństwa w Mohylowie nad Dniestrem w końcu XVIII wieku, „Przegląd Wschodni”, 14, 2017, 3 (55), s. 567-619

Kaliszewski W., Kilka uwag o wierszach czasu ostatniego bezkrólewia, „Napis”, 1998, seria 4, s. 45-55

Klimowicz M., Poczatki teatru stanisławowskiego (1765-1773), Warszawa 1965

Kott J., [wstęp do:] F. Bohomolec, Komedie na teatrum, Warszawa 1960, 1

Król B., Budynek Operalni saskiej w Warszawie, „Pamiętnik Teatralny”, 1956, 4, s. 631650

Meer van der J., The Casanova Duel in "Monitor" or Foreigners in the Literary Field of the Stanislavian Era, „Wiek Oświecenia”, 30, 2014, s. 137-150

Meer van der J., The Muchowski-Letter and the Introduction to "Matzeństwo z kalendarza". On Literary Production and Criticism in the First Years of the Stanistaw Age, ,Zeitschrift für Slawistik”, 44, 1999, 1, s. 93-102, https://doi.org/10.1524/slaw. 1999.44.1.93

Mikulski T., ,,Kurdesz nad kurdeszami”. Zagadnienie tekstu i autorstwa, „Pamiętnik Literacki”, 50, 1959, 1, s. 1-49

Morawski P., Oświecenie. Przedstawienia, Warszawa 2017

Opas T., Z problemów awansu społecznego mieszczan w XVII i XVIII wieku. O przenikaniu do stanu szlacheckiego i duchownego, „Przegląd Historyczny”, 65, 1974, 3, s. $465-477$

Ozimek S., Udziat „,Monitora” w ksztattowaniu Teatru Narodowego (1765-1785), Wrocław 1957

Raszewski Z., Staroświecczyzna i postęp czasu. O teatrze polskim 1765-1865, Warszawa 1963

Ratajczakowa D., Komedia oświeconych 1752-1795, Warszawa 1993

Rostworowski E., Wiedeńskie sperandy Poniatowskich i pierwszy rozbiór Polski, „Sobótka. Śląski Kwartalnik Historyczny", 38, 1983, 4, s. 527-536

Smoleński W., Mieszczaństwo warszawskie w końcu wieku XVIII, Warszawa 1917

Stopka K., Zięba A. A., Artwich A., Agopsowicz M., Ormiańska Warszawa, Warszawa 2012

Szymborski G., Wykorzystanie i kontrola wojska jako przedmiot gry politycznej i obrad sejmu konwokacyjnego $w$ dobie bezkrólewia 1764 roku, „Acta Universitatis Lodziensis. Folia Historica”, 98, 2017, s. 55-69, https://doi.org/10.18778/0208-6050.98.05

Tryjarski E., Ormianie w Warszawie. Materiały do dziejów, Kraków 2001

Wasyl F., Ormianie w przedautonomicznej Galicji. Studium demograficzno-historyczne, Kraków 2015, Studia Galicyjskie, 4 


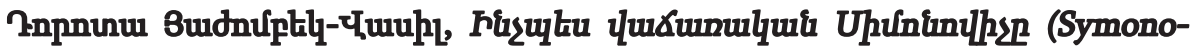

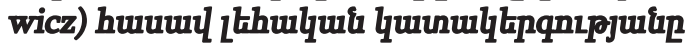

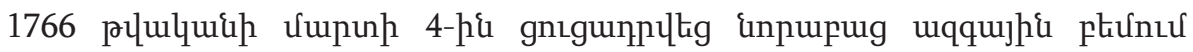

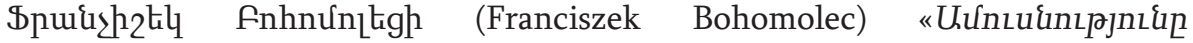

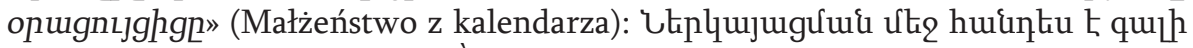

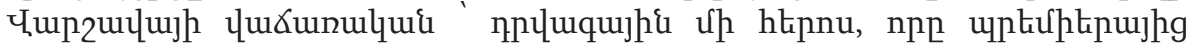

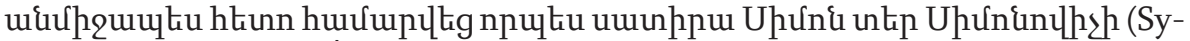

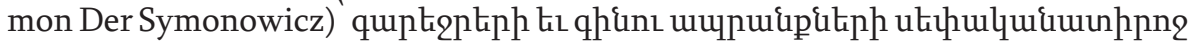

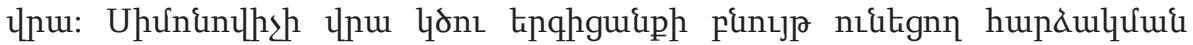

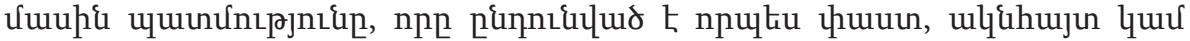

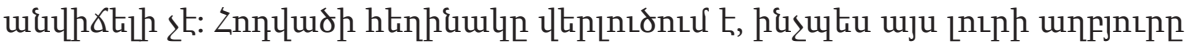

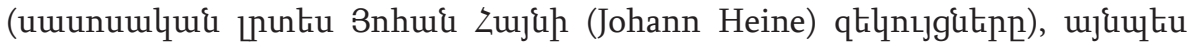

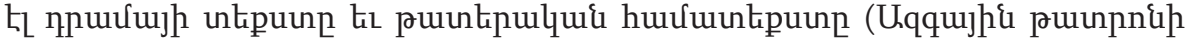

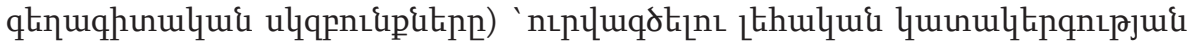

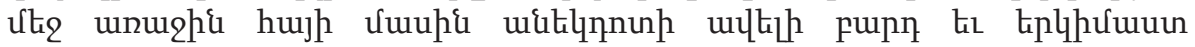
quipuuuuuununtpjnı\{n:

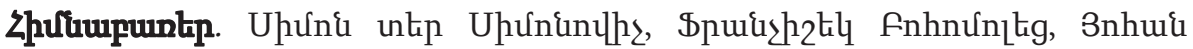

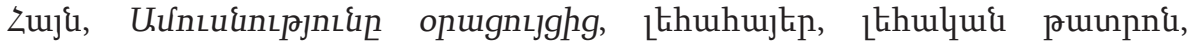

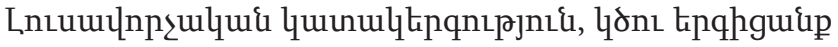

\section{Dorota Jarząbek-Wasyl, How Merchant Symonowicz Found his Way into Polish Comedy}

On $4^{\text {th }}$ March 1766, Franciszek Bohomolec's Matżeństwo z kalendarza ("Marriage by the Calendar") was performed in Warsaw on the newly opened national stage. The play features an episodic character of a Warsaw merchant who immediately after the premiere was recognised as a satire on Symon Der Symonowicz, the owner of breweries and manufacturer of wine goods. The account of the lampoon attack on Symonowicz, though accepted as a fact, can also be called into question. The author of the article examines both the origin of this circulating account (the reports of the Saxon agent Johann Heine) as well as the text of the drama and the theatrical context (the aesthetic principles of the National Theatre) to outline a more complex and ambiguous background of the anecdote about the first Armenian in Polish comedy.

Keywords: Symon Der Symonowicz, Franciszek Bohomolec, Johann Heine, Małzeństwo z kalendarza, Polish Armenians, Polish theater, Enlightenment comedy 